\title{
The Great Extinctions
}

David Penney

Acta Palaeontologica Polonica 58 (3), 2012: 560-560 doi: http://dx.doi.org/10.4202/app.2013.1001

Norman MacLeod 2013. The Great Extinctions: What Causes Them and How They Shape Life. 208 pp.

The Natural History Museum, London. Softcover. ISBN: 978-0-565-09278-8. Price: £14.99.

David Penney [david.penney@manchester.ac.uk], Faulty of Life Sciences, University of Manchester, Oxford Road, Manchester M13 9PL, UK.

This is an open-access article distributed under the terms of the Creative Commons Attribution License (for details please see creativecommons.org), which permits unrestricted use, distribution, and reproduction in any medium, provided the original author and source are credited.

Far 